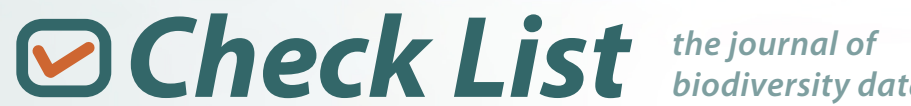

๑

\section{First record of Pogoniopsis Rchb. (Orchidaceae: Triphorinae) in Santa Catarina state, southern Brazil}

\author{
Felipe Bittencourt* and André L. de Gasper \\ Universidade Regional de Blumenau, Departamento de Ciências Naturais, Rua Antônio da Veiga nº 140, CEP 89012-900, Blumenau, SC, \\ Brazil \\ * Corresponding author. E-mail: 94bittencourt@gmail.com
}

\begin{abstract}
Pogoniopsis is an endemic and myco-heterotrophic orchid genus with only two species in Brazil that can be found growing under dense canopy. Pogoniopsis schenckii is more widely distributed, with records in the states of Bahia, Minas Gerais, Paraná, Pernambuco, Rio de Janeiro, and São Paulo. Here we record P. schenckii for the first time in Santa Catarina state, southern Brazil, in a subtropical broadleaved forest, as well the genus Pogoniopsis itself, expanding its southern distribution limit. In addition, a description and a distribution map of the collected specimens are presented.
\end{abstract}

Key words: myco-heterotrophic; rare species; endemic species; Atlantic Forest

Pogoniopsis Rchb. is an orchid genus endemic to Brazil characterized by small, achlorophyllous, myco-heterotrophic, herbaceous plants with scale-like leaves and yellow and white flowers that can be found growing under dense canopy and fertile soils (Cogniaux 1893-1896; Reichenbach 1881; Hoehne 1949; Pabst and Dungs 1975; Pansarin et al. 2012). There are currently only two recognized species (BFG 2015): Pogoniopsis nidus-avis Rchb.f. \& Warm., described in Reichenbach (1881), and Pogoniopsis schenckii Cogn., described in Flora Brasiliensis (Cogniaux 1893-1896), with little information about its morphology and a few descriptions in subsequent studies (Pabst and Dungs 1975; Abreu and Menini-Neto 2010; Pansarin et al. 2012).

The relationships of Pogoniopsis remain unclear, because morphological studies placed Pogoniopsis in subtribe Pogoniinae (Cameron and Chase 1999; Chase et al. 2003) or Triphorinae (Cameron 2003). In a morphological and molecular study, Pansarin et al. (2008) verified that Pogoniopsis shares many morphological traits with subtribe Galeolinae, but molecular data using ITS region suggest a basal position among tribe Pogonieae. Chase et al. (2015), however, argued that taxon sampling and molecular analyses were not sufficiently robust in that study, and again placed the genus in subtribe Triphorinae, closely related to Monophyllorchis Schltr., Psilochilus Barb.Rodr. and Triphora Nutt.

Comparing the two species, P. schenckii has the largest range, with previous records from Bahia, Minas Gerais, Paraná, Pernambuco, Rio de Janeiro, and São Paulo states, while $P$. nidus-avis is currently recorded only from Minas Gerais and Rio de Janeiro states (Pabst and Dungs 1975; Cardoso and Queiroz 2008; BFG 2015). Currently P. schenckii is categorized as Least Concern (LC) in the Red List of the Brazilian Centre for the Conservation of the Flora following IUCN Red List criteria, due to its large distribution area, no ornamental appeal, and occurrence in conservation units of integral protection (Prieto and Messina 2012).

During recent surveys in the Parque Nacional da Serra do Itajaí, Santa Catarina state, southern Brazil (Figure 1), specimens of a terrestrial, aclorophyllous orchid were found growing on soil, under dense canopy (Figure 2A). The local vegetation is classified as subtropical lower hills broadleaved forest according to Oliveira-Filho (2015). Specimens were photographed, collected and deposited in the Herbarium FURB (abbreviation follows Thiers 2016). The species was identified as $P$. schenckii through illustrations provided by Hoehne (1949) and Pabst and Dungs (1975). So far, this genus was not recorded in Santa Catarina state by BFG (2015) as well as in the Orchidaceae revisions by Pabst (1951, 1952, 1953, 1954, 1956, 1957, 1959).

The plate was edited with GIMP 2.8 and CorelDRAW X7 17.1 softwares. The distribution map was made using ArcGIS 10 software (ESRI 2010). Morphological terminology follows Font Quer (1953).

Pogoniopsis schenckii Cogn., Fl. Bras. 3(4): 136. 1893.

Plants terrestrial, herbaceous, achlorophyllous, mycoheterotrophic, $11.6-16.7 \mathrm{~cm}$ tall. Roots adventitious, 


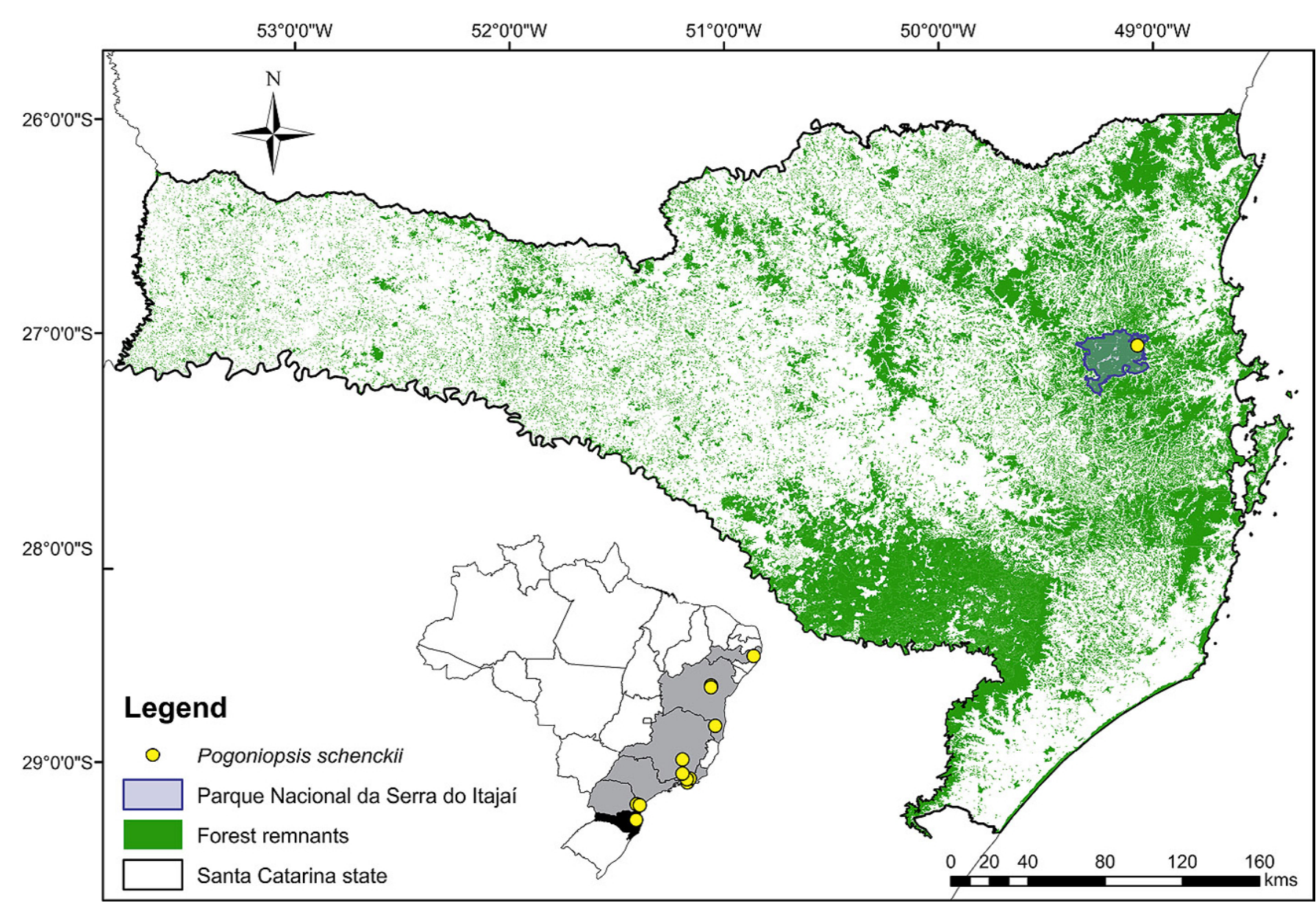

Figure 1. Location of the first record of Pogoniopsis in Santa Catarina state (black), southern Brazil and the current distribution of Pogoniopsis schenckii (gray).

pale brown, growing tip white, up to $28.3 \mathrm{~mm}$ long, 0.7-1.9 mm thick. Stalk erect, not branched, 2.6-6.3 $\mathrm{mm}$ thick. Leaves scale-like, sessile, covering stalk, broadly oblong to oblanceolate, apex acute, margin sometimes finely serrate to fimbriate, pale yellow to yellow, becoming black over time, 7.7-24.7 × 3.2-9.0 $\mathrm{mm}$. Inflorescence a raceme, terminal. Floral bracts yellow to brownish yellow, broadly elliptic, apex acute, margin finely serrate to fimbriate, 11.6-15.8 × 5.6-9.3 $\mathrm{mm}$. Flowers resupinate, odorless, perianth with a small pink portion at basis. Lateral sepals yellow, narrowlyoblanceolate, apex acute, $14.5 \times 3.2 \mathrm{~mm}$. Dorsal sepal broadly-oblanceolate, apex obtuse, yellow, white from middle to apex, $16.1 \times 5.8 \mathrm{~mm}$. Petals spathulate, apex obtuse, yellow, white from middle to apex, $15.3 \times 2.6$ $\mathrm{mm}$. Labellum 3-lobed, white, $15.2 \times 5.8 \mathrm{~mm}$. Side lobes erect, embracing the column, falcate, obtuse. Median lobe lanceolate with three hairy yellow stripes near the basis, margin finely laciniate to fimbriate in the middle. Column erect, slightly widened near the apex, pinkish white, $5.0 \times 2.0 \mathrm{~mm}$. Ovary white, $7.9 \times 3.6 \mathrm{~mm}$. Figure 2 .

Specimens examined: BRAZIL. Santa Catarina: Blumenau, Parque Nacional da Serra do Itajaí, $27^{\circ} 03^{\prime} 31.00^{\prime \prime}$ S, $049^{\circ} 04^{\prime} 41.00^{\prime \prime} \mathrm{W}$, elev. 340 m, 21/XI/2015, Bittencourt, F. and Schmitt, M.R. 635

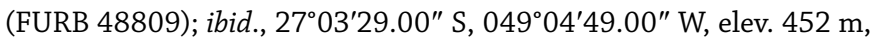
28/XI/2015, Bittencourt, F. and Bittencourt, F. 680 (FURB 48810).
Taxonomic comments: The 3-lobed labellum, the finely laciniate to fimbriate margin in the middle lobe and the bigger size of the plants distinguish this species from otherwise similar P. nidus-avis. Other remarkable features are the three hairy stripes in the labellum and the small pinkish portion at basis of perianth. Also, the measures provided by Cogniaux (1893-1896) are slightly larger than the measurements obtained from the examined specimens. The circumscription of the two species needs to be revalued, because the illustration in Cogniaux (1893-1896) disagrees from the one provided by Pabst and Dungs (1975).

Although Santa Catarina has a great history of field surveys and a well-known flora, many new records were made in recent years (Gasper et al. 2013a, 2013b, 2014; Funez and Gasper 2014; Hassemer et al. 2015; Funez et al. 2016), mostly provided by a large inventory survey performed in Santa Catarina (Vibrans et al. 2010). This new record should encourage new field surveys, even in a region where, since the 1940 s, botanical collection has been active (Reitz 1965). Not everything was collected and new records can be made, especially in rare, poorly collected, and neglected groups, as already stated for Pogoniopsis and its species (Cameron and Chase 1999; Menini-Neto et al. 2007; Pansarin and Barros 2008; Cameron 2009). In the Parque Nacional da Serra do 

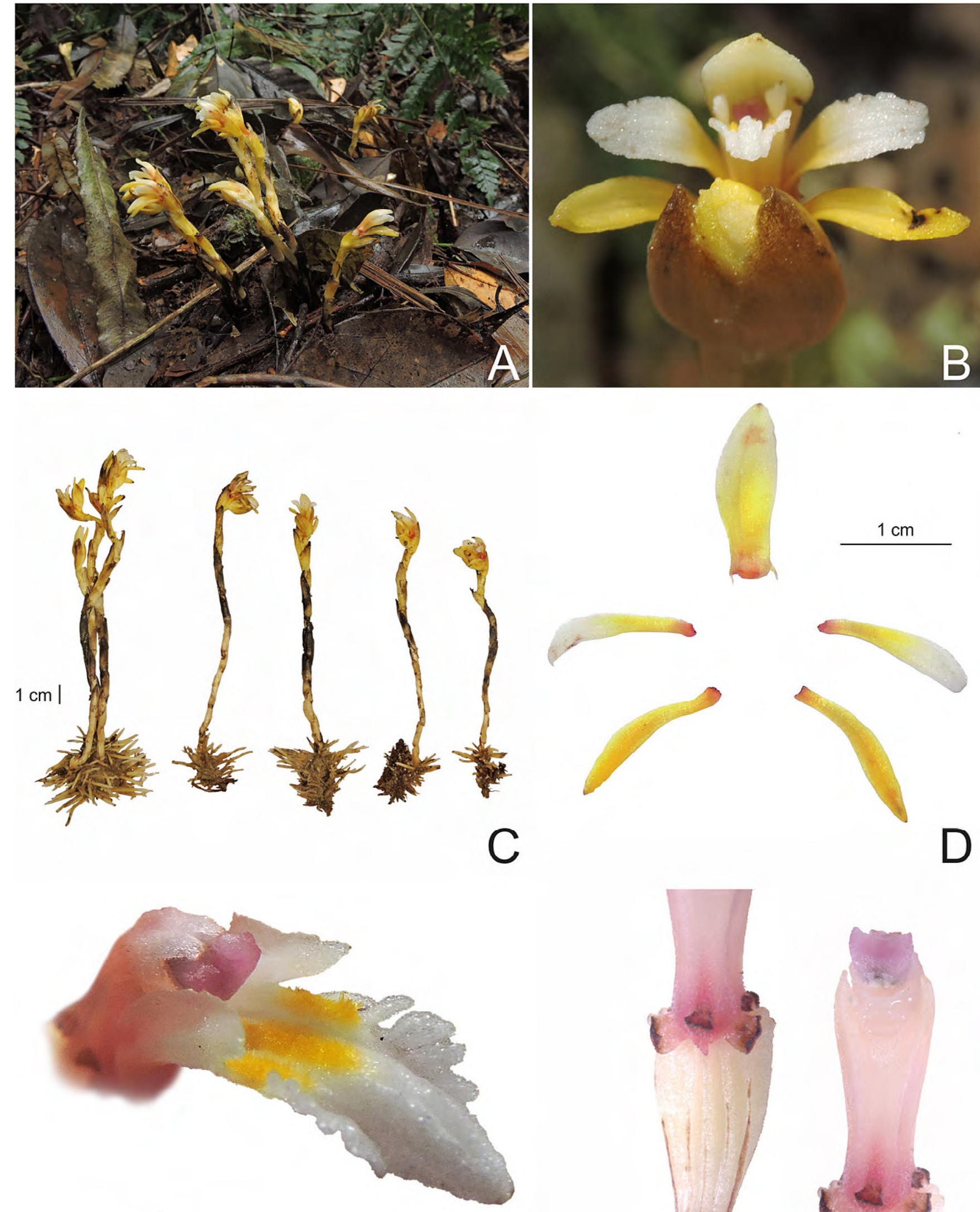

$1 \mathrm{~cm}$
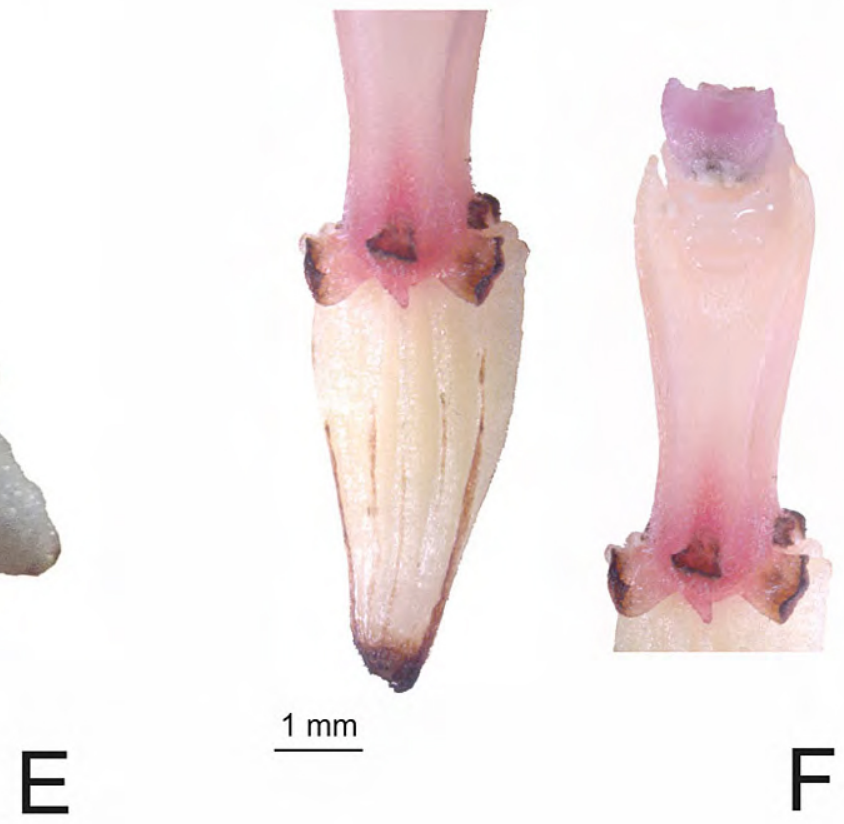

Figure 2. Pogoniopsis schenckii. A. General view of the plants and habitat. B. Detail of the flower. C. Habit, showing the adventitious root system. D. Dissected perianth, excluding the labellum. E. Detail of the labellum. F. Detail of the ovary and column. 
Itajaí, previous floristic studies dealing with shrubs and herbs did not record the genus (Funez and Gasper 2014). The small and disjunct populations of $P$. schenckii are probably maintained by means of autogamy (selfpollination), as already stated by Pansarin et al. (2012) for P. nidus-avis.

Preliminary microscopic analyses (Kemmelmeier pers. comm.) revealed septate fungal hyphae on the roots of the plants, not belonging to the Glomeromycota but to Ascomycota or Basidiomycota instead. However, there is no evidence that those hyphae belong to the mycobiont organism.

This is the first record of the genus for Santa Catarina state, as well as the southernmost record, as the previous southernmost record was in Paraná state (Pabst and Dungs 1975). As stated above, the species can be rare and with small populations, or have just being poorly collected, due to its short period of life. The record of the species in a protected area may mitigate threats that should not be dismissed until new records of this species are found.

\section{ACKNOWLEDGEMENTS}

The authors are thankful to the Universidade Regional de Blumenau and Parque Nacional da Serra do Itajaí for support, Aline A. Vale for the help with the description, Karl Kemmelmeier for the roots microscopic analysis, and Maurício R. Schmitt for the help during fieldwork.

\section{LITERATURE CITED}

Abreu, N.L. and L. Menini-Neto. 2010. As subfamílias Vanilloideae e Orchidoideae (Orchidaceae) em um fragmento da Serra da Mantiqueira, Minas Gerais, Brasil. Boletim de Botânica da Universidade de São Paulo 28(1): 15-33. doi: 10.11606/issn.23169052.v28i1p15-33

BFG (The Brazil Flora Group). 2015. Growing knowledge: an overview of seed plant diversity in Brazil. Rodriguésia 66(4): 1085-1113. http://rodriguesia.jbrj.gov.br/FASCICULOS/rodrig66-4/120043.pdf

Cameron, K.M. 2003. Vanilloideae; pp. 281-334, in: A.M. Pridgeon, P.J. Cribb, M.W. Chase and F.N. Rasmussen (eds.). Genera orchidacearum III. Oxford: Oxford University Press.

Cameron, K.M. 2009. On the value of nuclear and mitochondrial gene sequences for reconstructing the phylogeny of vanilloid orchids (Vanilloideae, Orchidaceae). Annals of Botany 104(3): 377-385. doi: 10.1093/aob/mcp024

Cameron, K.M. and M.W. Chase. 1999. Phylogenetic relationships of Pogoniinae (Vanilloideae, Orchidaceae): an herbaceous example of the eastern North America-eastern Asia phytogeographic disjunction. Journal of Plant Research 112(3): 317-329. doi: 10.1007/PL00013873

Cardoso, D.B.O.S. and L.P. Queiroz. 2008. Floristic composition of seasonally dry tropical forest fragments in central Bahia, northeastern Brazil. Journal of the Botanical Research Institute of Texas 2: 551-573. http://biodiversitylibrary.org/page/41650559

Chase, M.W., K.M. Cameron, R.L. Barrett and J.V. Freudenstein. 2003. DNA data and Orchidaceae systematics: a new phylogenetic classification; pp. 69-89, in: K.M. Dixon, S.P. Kell, R.L. Barrett and P.J. Cribb (eds.). Orchid conservation. Kota Kinabalu: Natural History Publications.
Chase, M.W., K.M. Cameron, J.V. Freudenstein, A.M. Pridgeon, G. Salazar, C. van den Berg and A. Schuiteman. 2015. An updated classification of Orchidaceae. Botanical Journal of the Linnean Society 177(2): 151-174.

Cogniaux, A. 1893-1896. Orchidaceae; pp. 1-672, in: C.F.P. Martius, A.G. Eichler and I. Urban. Flora brasiliensis 3(4). München: Lipsiae, apud F. Fleischer. http://biodiversitylibrary.org/item/9655

ESRI (Environmental Systems Research Institute). 2010. ArcGIS, version 10. Redlands: Environmental Systems Research Institute.

Font Quer, P. 1953. Diccionario de botánica. Barcelona: Editorial Labor. 1244 pp.

Funez, L.A. and A.L. Gasper. 2014. Parque Nacional da Serra do Itajaí (southern Brazil) shrub and herbs flora. Check List 10(6): 1249-1259. doi: 10.15560/10.6.1249

Funez, L.A., J.P.R. Ferreira, G. Hassemer and R. Trevisan. 2016. First record of the invasive species Rottboellia cochinchinensis (Poaceae, Andropogoneae) in the South Region of Brazil. Check List 12(4): 1930. doi: $10.15560 / 12.4 .1930$

Gasper, A.L., L. Sevegnani, A.C. Vibrans, M. Sobral, A. Uhlmann, D.V. Lingner, M.J. Rigon-Júnior, M. Verdi, A. Stival-Santos, S. Dreveck and A. Korte. 2013a. Inventário florístico florestal de Santa Catarina: espécies da Floresta Ombrófila Mista. Rodriguésia 64(2): 201-210. doi: 10.1590/S2175-78602013000200001

Gasper, A.L., A. Uhlmann, L. Sevegnani, D.V. Lingner, M.J. RigonJúnior, M. Verdi, A. Stival-Santos, S. Dreveck, M. Sobral and A.C. Vibrans. 2013b. Inventário florístico florestal de Santa Catarina: espécies da Floresta Estacional Decidual. Rodriguésia 64(3): 427-443. doi: 10.1590/S2175-78602013000300001

Gasper, A.L., A. Uhlmann, L. Sevegnani, L. Meyer, D.V. Lingner, M. Verdi, A. Stival-Santos, M. Sobral and A.C. Vibrans. 2014. Floristic and Forest Inventory of Santa Catarina: species of evergreen rainforest. Rodriguésia 65(4): 807-816. doi: 10.1590/2175-7860 201465401

Hassemer, G., J.P.R. Ferreira, L.A. Funez and R. Trevisan. 2015. First records of Melilotus albus Medik. (Fabaceae, Faboideae) in Santa Catarina, southern Brazil. Check List 11(1): 1499. doi: 10.15560/11.1.1499

Hoehne, F.C. 1949. Iconografia das orchidaceas do Brasil. São Paulo: Secretaria da Agricultura. 301 pp.

Menini-Neto, L.M., R.J.V. Alves, F. Barros and R.C. Forzza. 2007. Orchidaceae do Parque Estadual de Ibitipoca, MG, Brasil. Acta Botanica Brasilica 21(3): 687-696. doi: 10.1590/S0102-33062 007000300015

Oliveira-Filho, A.T. 2015. Capítulo 19: Um sistema de classificação fisionômico-ecológico da vegetação Neotropical: segunda aproximação; pp. 452-474, in: P.V. Eisenlohr, J.M. Felfili, M.M.R.F. Melo, L.A. Andrade and J.A.A. Meira-Neto (eds.). Fitossociologia no Brasil II: métodos e estudos de caso. Viçosa: Editora da Universidade Federal de Viçosa.

Pabst, J.F.G. 1951. Contribuição para o conhecimento das orquídeas de Santa Catarina e sua dispersão geográfica I. Anais Botânicos 3: $41-53$.

Pabst, J.F.G. 1952. Contribuição para o conhecimento das orquídeas de Santa Catarina e sua dispersão geográfica I (continuação). Anais Botânicos 4: 69-86.

Pabst, J.F.G. 1953. Contribuição para o conhecimento das orquídeas de Santa Catarina e sua dispersão geográfica I (conclusão). Anais Botânicos 5: 39-94.

Pabst, J.F.G. 1954. Contribuição para o conhecimento das orquídeas de Santa Catarina e sua dispersão geográfica II. Sellowia 6: 181-198.

Pabst, J.F.G. 1956. Contribuição para o conhecimento das orquídeas de Santa Catarina e sua dispersão geográfica III. Sellowia 7: $175-181$.

Pabst, J.F.G. 1957. Contribuição para o conhecimento das orquídeas de Santa Catarina e sua dispersão geográfica IV. Sellowia 8: 249-256. 
Pabst, J.F.G. 1959. Contribuição para o conhecimento das orquídeas de Santa Catarina e sua dispersão geográfica V. Sellowia 10: 161-177.

Pabst, J.F.G. and F. Dungs. 1975. Orchidaceae brasilienses I. Hildesheim: Schmersow. 408 pp.

Pansarin, E.R., A. Salatino and M.L.F. Salatino. 2008. Phylogeny of South American Pogonieae (Orchidaceae, Vanilloideae) based on sequences of nuclear ribosomal (ITS) and chloroplast ( $p s a B$, $r b c L$, rps16, and trnL-F) DNA, with emphasis on Cleistes and discussion of biogeographic implications. Organisms, Diversity and Evolution 8(3): 171-181. doi: 10.1016/j.ode.2007.09.003

Pansarin, E.R. and F. Barros. 2008. Taxonomic notes on Pogonieae (Orchidaceae): Cleistesiopsis, a new genus segregated from Cleistes, and description of two new South American species, Cleistes batistana and C. elongata. Kew Bulletin 63(3): 441-448. http://www. jstor.org/stable/20649578

Pansarin, E.R., A. Salatino, L.M. Pansarin and M. Sazima. 2012. Pollination systems in Pogonieae (Orchidaceae: Vanilloideae): A hypothesis of evolution among reward and rewardless flowers. Flora 207(12): 849-861. doi: 10.1016/j.flora.2012.09.011

Prieto, P.V. and T. Messina. 2012. Pogoniopsis schenckii Cogn., in: Lista Vermelha do Centro Nacional de Conservação da Flora. Jardim
Botânico do Rio de Janeiro. Accessed at http://cncflora.jbrj.gov. br/portal/pt-br/profile/Pogoniopsis_schenckii, 21 July 2016.

Reichenbach, H.G. 1881. Novitiae orchidaceae warmingianae. Otia Botanica Hamburgensia 2: 48-65. http://biodiversitylibrary. org/page/5868359

Reitz, R. 1965. Plano de coleção, in: R. Reitz (ed.). Flora Ilustrada Catarinense. Itajaí: Herbário Barbosa Rodrigues. 71 pp.

Thiers, B. [2016]. Index herbariorum: a global directory of public herbaria and associated staff. The New York Botanical Garden. Accessed at http://sweetgum.nybg.org/ih/, 21 July 2016.

Vibrans, A.C., L. Sevegnani, D.V. Lingner, A.L. Gasper and S. Sabbagh. 2010. Inventário florístico florestal de Santa Catarina (IFFSC): aspectos metodológicos e operacionais. Pesquisa Florestal Brasileira 30(64): 291-302. http://www.atlasorquideassc. com.br/arquivos/534c1e58e01fb.pdf

Author contributions: FB collected the specimens, FB measured and take photos of the specimens; FB and ALG wrote the text.

Received: 12 February 2016

Accepted: 12 October 2016

Academic editor: Mayara Caddah 